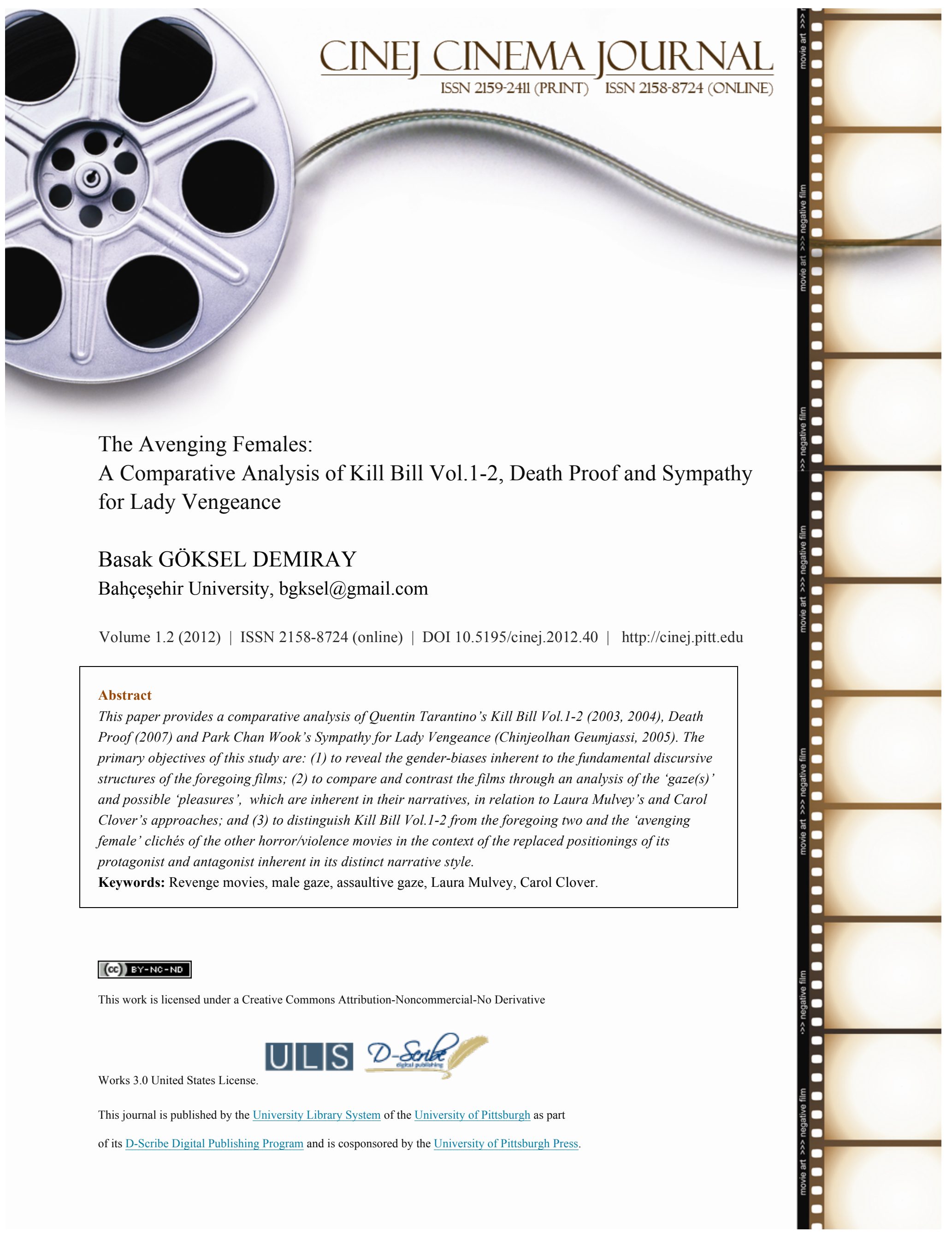




\section{The Avenging Females: A Comparative Analysis of Kill Bill Vol.1-2, Death Proof and Sympathy for Lady Vengeance}

" Revenge is never a straight line. It's a forest. Like a forest, it's easy to lose your way, to get lost, to forget where you came in." says Hattori Hanzo, the character who is the master of unique swords, in Kill Bill Vol. 1-2. Female victims who are ready to get their revenges in the following films - Kill Bill Vol.1-2 (Quentin Tarantino, 2003,2004), Death Proof (Quentin Tarantino, 2007) and Sympathy for Lady Vengeance(Chinjeolhan Geumjassi, Park Chan Wook, 2005) - come in a forest but never lose their ways. May be sometimes they get blind because of their pains and hates, but their path is exact, it is planned, it is memorized. It is impossible for them to get lost. In these three films women are very good at getting their revenges. They are the 'victim-heros'. They all succeed at the end of the films but they have different stories, located in different times and different places. Thus, I will try to compare and contrast these three films through the different paths of the stories of their female avengers. I will also try to elaborate the gaze(s) and some pleasures within their narratives and their directors' points of view.

In Kill Bill Vol. 1-2, there is a pregnant woman, Beatrix who is shot at her wedding rehearsal day, first by the assassination team of which she used to be the member. Then the leader of that team, Bill, is also her exboyfriend, shoots her in the head. After a four-yeared comatose, as she says in the film "she woke up, she went on what the movie advertisements refer to as a 'roaring rampage of revenge', she roared, she rampaged" and she continues that "I got bloody satisfaction." Here comes the 'pleasure' of giving harm, torturing and killing her assassins. Bill asks "Do you find me sadistic?" to Beatrix, but in fact she is the sadistic figure in the film. Bill makes Beatrix confirm that "she felt damn good, after all the people she killed to get to him. Because she is a killer." At this point, Kill Bill Vol. 1-2, differs from the other two films that I mentioned above. Because this 'avenging female' is a professional killer. Then here comes a new question, what is the real source of her satisfaction and her sadism? To be assassinated on her wedding rehearsal by her ex-boyfriend and his team? To be assassinated although she is pregnant? To be assassinated by the father of her baby although he knows that it's his baby? Or does she get a bloody satisfaction from killing because of her 'natural born killer' personality? In the other two films, women gets really hurt like Beatrix. Men hurt them - except the female members of the assassination team in Kill Bill Vol. 1-2, Bill is the responsible of their actions. After the big pains which men cause in women occur, women transform into a hero, and get their revenges in an effective way. After all the worst conditions they experienced as a victim, they become killers (In Sympathy for Lady Vengeance, I accept Geum-ja Lee as a killer, I will elaborate in the following). But in Kill Bill Vol. 1-2, killing is given to Beatrix as a job. I think, this is a crucial point that the director has chosen to destroy the cliché about the female avengers. Because in general, to be more effective and agitative, it is accepted that women should be victimized at the beginning, then because of her deep pain, she should realize her power, make some plans, decide to get her revenge and she should use a weapon in a non-professional way with a non-professional spirit.

Quentin Tarantino's this film is a complex but good example for the 'male gaze' . He choses a female protagonist. She is victimized in her wedding dress, carrying a baby, is shot in the head by the father of her baby, after a four-yeared comatose, she wakes up and sees that she has lost her baby. Then she plans to get her revenge from Bill. Bill is the unseen antagonist of the film until the vol. 2. In the first look, this story may seem as a pure feminist story. What can be more affective than the revenge of a pregnant bride, shot in the head by her baby's father? This might be a powerfull, strong, reborn woman's revenge and might get applause from the feminist spectators. But after the analysis of the film, some crucial points reveal the male gaze in the film within the characters in the narrative and within the director's point of view. 
In the narrative of Kill Bill Vol. 1-2, some male characters like the Sheriff, the old man namely Esteban who owns a brothel in Mexico, the gravedigger and Budd (Bill's brother) make comments about Beatrix's femaleness, blonde hair, eyes and beauty. She is the object of desire for them but she also deserves a punishment. At the beginning of the film we first see the bride from Bill's (dominant antagonist male) point of view. Then the second time is from behind the green sun-glasses of the Sheriff. He says "man would have to be a mad dog to shoot a goddamn good looking gal like that in the head. Look at her, hay coloured hair, big eyes, she is a little blood- spattered angel" (i.e. if that girl would not be shot, she will be a good object in Laura Mulvey's definition of male gaze). When she spits to his face, the Sheriff says "this tall drink of cocksucker ain't dead.", he refers male's dominance and female's passivity here. By defining her as a "cocksucker", he punishes her in his mind for spitting to his face. Esteban the other male character, when first sees Beatrix, he finds her very beautiful and explains Bill's admiration about blondes that coming from his childhood and continues "if I were Bill, I would cut your face instead of shooting you in the head." He accepts and praises her beauty but he wants to punish her because of it. In addition to these, in the burying scene, Budd asks to the gravedigger man "Is she the cutest little blonde pussy you ever saw?", he answers "I've seen better", then Budd asks Beatrix "you got anything to say?" and she does not answer, the gravedigger says "white women call this 'the silent treatment' and we let them think we don't like it". That's to say, when a woman does not answer a man's question, man punishes her in a way and makes woman think that he does not like to get no answer to his question. The gravedipper man refers to burying her as a punishment for her silence. Before Budd, I would also like to elaborate two males in the hospital. Buck the Fuck and his client rapist. They are the perverse examples of the male gaze. They get pleasure from raping a woman who is in a comatose. They look at and have her body to satisfy their morbid sexual pleasures. Buck the Fuck, warns another man not to beat, punch or leave marks on her. This also refers to 'sadistic pleasures' that males get from the bodies of females. It is also necessarry here to mention Pai Mei's - who is the master of far eastern fighting techniques - gaze to females, at the beginning he was full of bias about Beatrix. In his opinion, she was weak, the only thing she can do is to "order in restaurants and spend man's money like all yankee women". But then, when Beatrix begins to success in the trainning and gets some skills that only man can have, she seems masculine to him. He gives up all his prejudice about her femininity and he teaches a unique technic to her that he has not teach anybody before.

These male characters that I have tried to elaborate above, all have Carol Clover's "assaultive gaze" on females in a minor or major way. Beatrix has confronted their assaultive gazes in her most weakest, powerless, passive or feminine moments. But in fact Beatrix Kiddo is constructed as a powerfull, skillfull, angry, sadistic and masculine 'female avenger'. She wears masculine costumes(sweat-suits, sport-shoes, jeans, leather jackets, boots), fights perfect, knows far eastern fighting techniques, uses weapons (especially knives and swords like a samurai) very well, drives motor-cycles, she even can go out of a nailed coffin in a grave, kills dozens of O-Ren Ishii's guards and the list goes on. Shortly she is a perfect killer and avenger. These kind of female heros and avengers represent a progress in a male-dominant, patriarchal cinema conventions. As I mentioned above this could be a perfect feminist story, but the director's male gaze reveals itself in his choices.

First, he does not choose Beatrix's all enemies from the males. She has three major female enemies. The first one O-Ren Ishii and her dozens of guards are easily killed by Beatrix. Then Vernita Green tries to deceive her and aims catching her undefended but Beatrix repulses Vernita's attack with her strong reflex and kill her. When it's Budd's turn, she fails. He is the one who defines Beatrix as "she is as clever as how much a blonde female can be." He shots her in her chest, anaesthetize, and bury her alive. He achieves this because he makes a counterplan to her possible assault. She could not kill him. The second important male character in the film is not killed by her hands. Then Beatrix assaults Elle Driver, removes her eye and leaves her alone with a poisonous snake in the caravan. After all, now, it's time to kill Bill. Although he says at the beginning of the film that he is at his most masochistic moment when he is ready to pull the trigger to shoot Beatrix in the head, carrying his baby. The 
spectator does not believe his words because until the confrontation with Beatrix in the final sequence, he is presented us as the antagonist of the film. During the film, the spectator wants as much as Beatrix wants to find and kill Bill. This will be elaborated as the second choice of Tarantino.

Tarantino does not treat to Beatrix and to her revenge as an honorable and holly thing. She would be the holliest creature if she could kill the antagonist which the spectator have imagined as a sadistic, brutal male. But the confrontation of presented Protagonist (Beatrix) and presented Antagonist (Bill) confuses us. Because we have seen Bill as a good father, playing with his and Beatrix's alive daughter, preparing meals to her, listening to her stories about her dead fish, appreciating her honesty about the death of her fish and making her asleep. He insisted on explaining how he loved and still loves Beatrix. He asked the reason why she left him, why she let him to think that she is dead, and why she hide her pregnancy from him. Through Bill's lines, Tarantino wants us to understand that he really was at his most masochistic moment when he was shooting the woman he loves carrying his baby. In this crucial scene, the director wants us to change our minds about the presented protagonist and the presented antagonist. As a dominant male in the film Bill made Beatrix, to confess that she is a killer, she is a natural born killer, satisfying herself by killing other people. She confessed. He tried to impose her that she did wrong, she should not have gone with his baby, she should not leave him. The director tries to make the spectator identify with also Bill now. He thinks he is right and says "there are conscequences to breaking the heart of a murdering bastard. You experienced some of them. Was my reaction really that surprising?". He tried and tries to make Beatrix a passive female, living under his authority, devoted herself to him. He does not want a woman making some decisions without asking him. He tries to tell her that she should have known that he is a that kind of man. This scene contains confessions of both sides. If each member of a couple is professional killers, which one might be right in this revenge story? If a woman betrays her killer lover, it might be the first and easy thing for him to shoot her. Or if a man shoots his killer lover carrying his baby, it might be the first and easy thing for her to get revenge.

In short, if Kill Bill Vol. 1-2 were a just female avenging story (feminist story), the spectator may hardly find male gaze(s) in it. But the director Quentin Tarantino, although he does not present his female hero as a sexual object to male spectators through masculinizing her with her outside appearance and her masculine skills, he constructed some male characters to treat her as she is a passive female who deserves to be punished, and as they are dominant that I have detailed above. He constructed female enemies for Beatrix and made her kill them succesfully but the male enemy Budd was a fail. In addition to these, the director also let the antagonist to defend himself, to explain his reason and to show himself as a good father. He also constructed the protagonist as a professional killer instead of a ingenuous, vulnerable female. Here, I may also add the fetishistic pleasures (female feet, and yellow related to females - sweatwears, shoes, motorcycle, pussy cat wagon, and Beatrix's blonde hair) of the director as the signifier of his own male gaze.

In Death Proof, his fetishes about female feet and yellow (cars, costumes) continues. Female legs and butts also can be added as the new ones. Death Proof has not only one female avenger, it has three ones. Two of these girls, Kim and Zoe, presented as masculine female figures like Beatrix. They work as stunt women in Hollywood films. They do not wear short skirts or shorts like the other girls in the film. They are interested in cars, speed, adventure. The third one Abbie is not seem as masculine as the other two but she is the one who does not have sex with her boyfriend. These three are all non-sexual characters like Beatrix. Kim carries a gun in case of any threat might come from men. She thinks that women need to carry a gun in the world that she lives. She is right. If there is a maniac man around, named Stuntman Mike, every women may need a gun. Tarantino constructs him as a tough, sadistic, sexually perverted man. He is interested in his car a lot, he likes speed. He gets sexual satisfaction when he kills women with his car. His car is the symbol of his power. He kills four women- by 
crashing their car with his car- before he confronts Kim, Zoe and Abbie. In the narrative, we learn from the Sheriff (the same one in Kill Bill vol. 1-2) that, "the Judge does not find him guilty, because he is clean, but the four dead women were drunk and stoned." This reasoning is an example of the male gaze in the film. Females are guilty, because they drink alcohol and smoke joints. They are punished. In the film Tarantino often represents femalesespecially which are killed- as the object of scopophilic-fethishistic look of males. They have beautiful bodies, especially legs and butts. They wear sexy clothes. In Kill Bill vol. 1-2, women are not represented as sexy as they are in Death Proof. All women in this film, are also objects of sadistic- voyeuristic look of Mike. He peeps them from his car and takes their pictures. During the film all female characters talk about their relationships with males. Some has boyfriends and some does not. The sum of their dialogues is, men are unreliable and sometimes dangerous. Some male characters at the bar prove this unreliability and danger that they all the time have sexual purposes on females. They plan to make women drink a lot and then force them to go to the house which is not permitted by one of the girls's father to stay with males. Thus, in the effect of all long-term dialogue-oriented scenes of females, scenes of males at the bar and the sadistic killings and peepings of Mike, at the end of the film, we as a spectator, share the females's victory. Kill Bill vol. 1-2 is a film with fewer dialogues than Death Proof. Action scenes are dominant in the film but until the final sequence with Bill - because this final sequence has long dialogues - we follow Beatrix's actions with excitement, we support her, believe her, she does not need to talk, she has an excellent performance to reflect her revenge. May be the 'masculinity' is the good formula to identify with the female avenger. May be as both fe/male spectators, because we are used to male heros, we identify with the masculine 'heroines' more easily. Death Proof's avengers are the masculine ones as I mentioned above.

In Sympathy for Lady Vengeance, Geum-ja Lee is not a masculine female avenger- she is seen most feminine after a sex with a man, her dressing and gestures are also feminine. She makes us believe in and feel her story deeply. She is a woman who has prisoned for thirteen years because of a morbid child kidnapper-killer male. This male was her english teacher. He takes nobody's attention as a kidnapper-killer because of his social status of being a teacher. He impregnates Geum-ja Lee, when she was at the high school. She, as a pregnant teenager has nowhere to go, she is scared of her family and starts to stay with the teacher. Then she witnesses him killing a little boy and he blackmails her that if she does not take the blame of killing the boy, he will tell everybody that she has a illegitimate baby. Thus, she is prisoned instead of him as the killer of the boy. She leaves her little daughter behind. In the prison, she plans how to get her revenge for 13 years. She has a detailed plan. She requests some women who finish their times in prison to help her, to find him and to live around him. One of them accepts to try to be his girlfriend. Geum-ja Lee appreciates her that she accepted to be a girlfriend of this maniac man. When she successes to be his girlfriend and to live with him, Geum-ja Lee pays for the cost of the girl's favour with killing another woman in the prison who has tortured the girl for many years when she was in prison. This is the first killing of Geum-ja Lee with a chemical given within the torturer woman's meals in the prison. Then after thirteen years, she is free and she decides to wait. She is always in contact with the girl and gets information from her about the teacher. She waits for the right time. While waiting, she finds her daughter then she buys a gun, plans everything with her prison-friends. When it's time to kill him, she decides to let the families of dead children be first to get their revenges. She finds and prepares all the weapons, calls the families, collects them in an empty school building, shows the tapes of their children's killings than asks if they want to get their revenges. Of course they all want. Then they torture the teacher one by one. After his death, they bury him in an empty field. Geum-ja Lee shoots his dead body while the others are putting him into the grave. She gets her revenge by letting the families to get their revenges one by one. She is satisfied with being a witness to the families when they feel themselves tranquil and reborn after the tortures. Geum-ja Lee gets a big sadistic pleasure, when she sees him being buried after all the tortures of families and she shoots his dead body at the end to fulfil her duty for her unfortunate memories. 
In this effective female avenging story, the antagonist is similar to the stuntman Mike. Both are perverted, both deserves to be killed in a disgusting and harsh way. In Sympathy for Lady Vengeance, similar to the stuntman Mike, the teacher is perverted as a killer and also he is perverted in his sexual desires. Mike gets sexual satisfaction by killing women with his car and the teacher takes pleasure from kidnapping children, killing them even their families give the ransom to save their children's lives and also from recording them with a handicam while they are dying. On the contrary, Bill is not presented as that kind of men. He is presented as a deeply lover and as a good father, but unfortunately a killer. Also Bill dies in a respectable and noble way, with a technique that Pai Mei teaches nobody even to Bill. He dies because of the attack coming from the woman he loves to his heart, it is the same heart belongs to her.

In conclusion, this study puts forward that although aforedetailed three films are all revenge stories of their female victim-heros, Quentin Trantino's Kill Bill vol. 1-2 differs from the other two in positioning its protagonist and antagonist in the narrative. The complexity inherent in its final sequence distinguishes Kill Bill vol. 1-2 from the cliches of other avenging female stories. The question of how Kill Bill vol. 1-2 distinguishes from the other horror/violence films, especially from Death Proof and Sympathy for Lady Vengeance is revealed by the analysis of 'gaze(s)' and the possible 'pleasures' Mulvey and Clover defined. 


\section{Bibliography}

Clover, Carol J. (1993), Men, Women and Chain Saws: Gender in the Modern Horror Film. New Jersey: Princeton University Press.

Mulvey, Laura (1975), "Visual Pleasure and Narrative Cinema" in Visual Culture: The Reader, ed. by Jessica Evans and Stuart Hall, Sage Publications, pp. 381-390.

\section{Endnotes}

Laura Mulvey, in her article titled "Visual Pleasure and Narrative Cinema" argues that, there are two kinds of pleasures in the conventional cinematic situation. (1) Scophophilic: "arises from pleasure in using another person as an object of sexual stimulationthrough sight; (2) Narcisstic: "comes from identification [of the ego] with the image seen." (Mulvey, 1999: 383) In line with this, according to Mulvey, "in a world ordered by sexual imbalance, pleasure in looking has been split between active/ male and passive/ female. The determining male gaze projects its phantasy on to the female figure which is styled accordingly. In their traditional exhibitionist role women are simultaneously looked at and displayed, with their appearance coded for strong visual and erotic impact so that they can be said to connote to-be-looked-at-ness. [...] Traditionally, the woman displayed has functioned on two levels: as erotic object for the characters within the screen story, and as erotic object for the spectator within the auditorium, with a shifting tension between the looks on either side of the screen." (Mulvey, 1999: 383)

Sadistic pleasure: "lies in ascertaining guilt (immediately associated with castration), asserting control and subjecting the guilty person [female] through punishment or forgiveness." (Mulvey, 1999: 386)

Carol Clover points out that "assaultive gaze, figured as masculine [sadistic], of the camera (or some stand-in)" in modern horror films. (Clover, 1993: 181) In the extent of this study, 'assaultive gaze' is employed to be more clear in the elaboration of Beatrix Kiddo from the perspective of the sadistic/active/pejorative male characters.

According to Mulvey, males disavow the castration "by the substitution of a fetish object or turning the represented figure itself into a fetish so that it becomes reassuring rather than dangerous (hence over-valuation, the cult of the female star). (Mulvey, 1999: 386) 